\title{
Konsep “One Stop Browsing" di Perpustakaan Perguruan Tinggi sebagai Upaya Mewujudkan Layanan Informasi yang Rekreatif
}

\author{
Sri Wahyuni \\ Perpustakaan Institut Agama Islam Negeri Batusangkar \\ email: sriwahyuni@iainbatusangkar.ac.id
}

\begin{abstract}
Abstrak
Di era modern saat ini fungsi perpustakaan perguruan tinggi sebagai pusat layanan informasi dituntut untuk bertransformasi guna memenuhi kebutuhan informasi dan eksistensinya di tengah masyarakat. Namun masih banyak perpustakaan perguruan tinggi yang mempunyai fasilitas lengkap, namun belum banyak dikunjungi oleh pengguna karena masih terkesan kaku dan kurang nyaman. Hal ini perpustakaan dapat mengadopsi konsep dari pelayanan market, dimana penataan barang, desain interior dan eksterior ruangan yang membuat kita nyaman dan ingin berada lama disana ditambah dengan service yang memuaskan pelanggan. Penelitian ini menggunakan jenis penelitian kualitatif dengan pendekatan studi kepustakaan (library research). Dalam menganalisis data peneliti menggunakan teknik analisis isi (content analysis). Salah satu konsep yang menarik untuk mewujudkan perpustakaan yang rekreatif adalah dengan mengaplikasikan konsep "One Stop Browsing" yaitu sebuah konsep dimana perpustakaan dapat menyediakan bermacam-macam layanan perpustakaan di dalam satu gedung secara lengkap, bertujuan agar pengunjung tak perlu lagi harus pergi keluar gedung untuk mencari bahan pustaka yang dibutuhkan. Adapun beberapa fasilitas penunjang yang dapat disediakan di perpustakaan antara lain: lobby, lounge library, counter mini, computer searching, mesin fotocopy, internet, ruang teater, dan televisi.
\end{abstract}

\author{
Kata kunci : \\ One Stop Browsing, \\ Perpustakaan \\ Perguruan Tinggi, \\ Layanan Informasi, \\ Rekreatif
}

\section{A. PENDAHULUAN}

Untuk mewujudkan perpustakaan yang proaktif dan antisipatif, dalam Undang-Undang Perpustakaan No. 43 Tahun 2007 Pasal 1 disebutkan bahwa perpustakaan adalah institusi pengelola koleksi karya tulis, karya cetak, dan karya rekam secara profesional dengan sistem yang baku guna memenuji kebutuhan pendidikan, penelitian, pelestarian infrmasi dan rekreasi pemustaka. (Perpustakaan Nasional, 2007). Perkembangan teknologi dan informasi secara berangsur-angsur menghendaki adanya perubahan dalam pengelolaan layanan informasi yang dapat diperoleh dengan mudah dimana saja. Hal ini menuntut perpustakaan lebih berperan dalam pelayanan informasi terkini.

Oleh karena fungsi perpustakaan yang sangat penting, maka telah berdiri macam-macam perpus- takaan, baik perpustakaan umum, perpustakaan khusus, perpustakaan sekolah, maupun perpustakaan perguruan tinggi. Perpustakaan perguruan tinggi sebagai perpustakaan yang mengemban fungsi dalam menciptakan sarjana yang mampu menerapkan dan mengembangkan ilmu pengetahuan, teknologi dan seni, maka keberadaan perpustakaan di perguruan tinggi merupakan suatu keharusan dalam sebuah lembaga pendidikan.

Fungsi utama perpustakaan perguruan tinggi adalah memberikan layanan kepada civitas akademika di bidang pstaka dalam rangka pelaksanan Tri Dharma Perguruan Tinggi berupa pendidikan, pengajaran, penelitian dan pengabdian di masyarakat (Suroeno, 2016). Namun perkembangan selanjutnya perpustakaan perguruan tinggi belum mampu memberikan layanan informasi yang memadai. Permasalahan utama adalah rendahnya 
angka kunjungan mahasiswa dan pengajar ke perpustakaan. hal ini tentunya berkaitan dengan performa perpustakaan akibat minimnya sumber daya manusia dan minimya anggaran perpustakaan perguruan tinggi. Sehingga civitas akademika lebih memilih layanan informasi melalui tempat lain untuk tidak sama sekali yang berakibat pada rendahnya prodiktivitas perguruan tinggi.

Berkaitan dengan hal tersebut, muncul sebuah konsep baru "One Stop Browsing" yang berawal dari konsep "One Stop Shopping" di market, yang tujuannya agar menarik minat pelanggan untuk belanja. Konsep ini diharapkan dapat mewujudkan perpustakaan perguruan tinggi sebagai layanan yang rekreatif bagi pemustaka.

Berdasarkan latar belakang di atas, maka tulisan ini akan membahas bagaimana peran konsep "One Stop Browsing" di perpustakaan perguruan tinggi dalam upaya mewujudkan layanan informasi yang rekreatif.

\section{B. KAJIAN TEORITIS}

\section{Perpustakaan Perguruan Tinggi}

Perpustakaan perguruan tinggi adalah perpustakaan yang terdapat pada perguruan tinggi, badan bawahannya, maupun lembaga yang berafiliasi dngan perguruan tinggi dan tujuan utama membantu perguruan tinggi mencapai tujuannya (Basuki, 2002).

Di samping itu menurut Zein (2006) juga mengemukakan bahwa perpustakaan perguruan tinggi adalah perpustakaan yang berada di lingkungan lembaga perguruan tinggi lainnya.

Dari uraian diatas maka penulis menyimpulkan bahwa perpustakaan perguruan tinggi merupakan sebuah insititusi pendidikan yang berada dibawah lembaga perguruan tinggi yang bertugas memberikan pelayanan informasi di kalangan civitas akademika yang tujuannya selaras dengan organisasi induknya.
Secara umum tujuan perpustakaan perguruan tinggi adalah:

a. Memenuhi keperluan informasi masyarakat perguruan tinggi, lazimnya pengajar dan mahasiswa, mencakup pula tenaga administrasi dan perguruan tinggi;

b. Menyediakan bahan pustaka (referens) pada semua tingkat akademis, artinya mulai dari mahasiswa tahun pertama hingga ke mahasiswa program pascasarjana dan pengajar;

c. Menyediakan ruang belajar untuk pemakai perpustakaan;

d. Menyediakan jasa peminjaman yang tepat guna bagi berbagai jenis pemakai;

e. Menyediakan jasa informasi aktif yang tidak saja terbatas pada lingkungan perguruan tinggi tetap juga lembaga industri lokal (Basuki, 2013).

Perpustakaan perguruan tinggi dibentuk untuk memenuhi kebutuhan informasi civitas akademika perguruan tinggi yang bersangkutan, yaitu mahasiswa dan dosen. Namun banyak juga perpustakaan memberikan layanan kepada pemustaka di luar lembaga pendidikannya. Perpustakaan perguruan tinggi berfungsi sebagai sarana yang akan menunjang proses perkuliahan dan penelitian di perguruan tinggi tersebut.

Dalam Undang Undang Nomor 20 Tahun 2003 tentang Sistem Pendidikan Nasional Pasal 55 menyebutkan bahwa salah satu syarat untuk menyelenggarakan perguruan tinggi harus memiliki perpustakaan. sedangkan Perpustakaan Perguruan Tinggi (PPT) merupakan unit pelaksana teknis yang bersama-sama dengan unit lain melaksanakan Tri Dharma Perguruan Tinggi dengan cara menghimpun, memilih, mengolah, merawat, serta melayani sumber informasi kepada lembaga induk khususnya dan masyarakat akademis pada 
umumnya.

Dengan demikian, keberadaan perpustakaan perguruan tinggi dipandang strategis dalam pengembangan ilmu pengetahuan dan teknologi. Secara umum peran perpustakaan perguruan tinggi adalah memberikan pelayanaan informasi yang dibutuhkan oleh pemustakanya. Karena salah satu tolak ukur dari keberhasilan dari perpustakaan adalah apabila berhasil memenuhi atau memuaskan informasi yang dibutuhkan pemustaka.

\section{Kondisi Umum Perpustakaan Perguruan Tinggi}

Performa dari perpustakaan perguruan tinggi kita dapat dilihat dari kondisi fisik perpustakaan dan situasi ruangan. Secara umum perpustakaan perguruan tinggi memiiki gedung perpustakaan yang memadai. Hal ini ditandai dengan bangunan fisik yang luas, tinggi dan megah, terkadang karena koleksi pustaka yang dipunyai kurang, sehingga terkesan banyak rak-rak buku kosong yang tidak dimanfaatkan.

Sebaliknya, dapat kita lihat di beberapa bagian ruang mempunyai koleksi yang berlimpah tetapi hanya berisi buku-buku yang kurang update dengan perawatan ala kadarnya. Hal ini mengurangi minat untuk berk unjung ke perpustakaan, baik membaca atau meminjam koleksi. Jika kita ingin jujur, situasi perpustakaan perguruan tinggi cenderung tertutup dan terkesan membosankan. Penataan ruang yang monoton, ruang-ruang hanya terisi buku dan meja baca, terlebih hal ini terjadi pada perpustakan tradisional.

Kondisi ini terkait dengan rendahnya sumberdaya manusia (SDM) dan rendahnya anggaran yang disediakan pada perpustakaan perguruan tinggi dimana hal ini akan berlimpah terhadap birokrasi pelayanan pada perpustakaan perguruan tinggi (Basuki, 2002).

Dalam menjalankan fungsinya perpustakaan sebagai pusat layanan informasi, perpustakaan dituntut untuk menyediakan SDM yang mampu melayani kondisi kebutuhan informasi pemustaka. Untuk mengubah kondisi tersebut perpustakaan hendaknya segera melakukan pembenahan menyeluruh, untuk meningkatkan mutu pelayanan. Di sisi lain sebagai bagian dari masyarakat yang terus berubah, layanan perpustakaan hendaknya berada pada arus yang sama yaitu layanan yang didasarkan pada prinsip mensejahterakan masyarakat pemustaka.

Masalah utama dalam pengembangan perpustakaan perguruan tinggi seperti perguruan tinggi negeri adalah rendahnya anggaran dan sistem birokrasi pengadaan. Menurut Sulistyo Basuki masih banyak perpustakan perguruan tinggi yang memiliki anggaran jauh di bawah 5\% bahkan banyak perpustakaan perguruan tinggi yang hampir tidak punya anggaran. Jangankan mencoba berinovasi dan menciptakan situasi ruangan perpustakaan yang menyenangkan dan menarik bagi pengunjung, menambah koleksi saja sangat sulit realisasinya. Kalaupun toh dapat mengajukan pengembangan perpustakaan, seperti pembelian buku perpustakaan sebagai unit pelaksana teknis pengembangan perpustakaan harus melalui bagian/biro pengadaan barang perguruan tinggi yang terkadang memiliki perbedaan misi dan visi yang diemban. Hal ini akan menjadi kendala dalam mewujudkan perpustakaan perguruan tinggi sebagai pusat layanan informatif yang rekreatif, dimana peran pustakawan dituntut aktif dalam pengembangan informasi sesuai dengan kebutuhan pemustaka.

\section{Pusat Layanan Informasi yang Rekreatif}

Perpustakaan sebagai pusat layanan informasi menjadi tulang punggung penggerak maju mundurnya suatu institusi, terutama institusi pendidikan pada perguruan tinggi, maka perpustakaan 
harus mampu mengikuti perkembangan informasi yang terkini. Hal ini dikarenakan pemustaka dominan berasal dari kalangan akademisi sehingga mau tidak mau perpustakaan harus berfikir untuk berupaya mengembangkan diri guna memenuhi kebutuhan masyarakat informasi.

Idealnya perpustakaan yang menyenangkan adalah dimana dalam suatu gedung perpustakaan terjadi kegiatan yang sangat sibuk yang dilakukan setiap individu per individu. Semua kegiatan tidak mengalami hambatan yang berarti baik pemustaka maupun pelayanan perpustakaan. dimana semua kegiatan dilakukan dengan tertib dan tenang.

Menurut Franz dan Meier (1983) tanpa harus meninggalkan kaidah-kaidah utama pengelolaan perpustakaan, faktor rekreasi di dalam perpustakan sebenarnya dapat diunggulkan, karena dari sana memungkinkan banyak pengunjung yang berdatangan. Penelitian empiris dapat menunjukkan bahwa di hampir semua jenis sekolah, motif membaca "pertama-tama adalah sebagai hiburan", dan ini jauh melebihi membaca untuk kepentingan belajar.

Berdasarkan hal tersebut tidak ada salahnya kita mengambil kesempatan dari para pelajar yang hanya sekedar membaca sebagai hiburan untuk bisa berkunjung ke perpustakaan. sementara kita telah menyiapkan tempat yang nyaman untuk menarik minat baca mereka menuju bahan pustaka lain yang lebih dari sekedar rekreasi. Sebagai contoh di banyak toko buku di ibukota memiliki penampilan yang hangat dan menyenangkan bagi pengunjung. Tak ada lagi rak-rak buku persegi degan buku yang sara berjejalan. Tetapi di isi beberapa sofa dan meja tunggal, rak buku melingkar, bahkan kursi tinggi untuk balita disediakan. Hal itu sudah banyak dilakukan di toko buku di jepang dan singapura sekurang-kurangnya lima tahun yang lalu.

Bagaimana dengan perpustakaan kita? apakah kita mampu mengubah kesan tradisional yang selama ini dianut, menjadi sedikit lebih hangat dan bersahabat. Memang konsep perpustakaan berbeda dengan toko buku yang lebih bersifat komersil yang mempunyai target penjualan dan dihitung dengan rupiah, tetapi bukankah perpustakaan perguruan tinggi juga mengemban tugas dalam memberikan pelayanan terhadap civitas akademika dalam rangka melaksankan Tri Dharma Perguruan Tinggi.

\section{METODE PENELITIAN}

Jenis penelitian yang digunakan adalah penelitian kualitatif dengan pendekatan studi kepustakaan (library research). Studi kepustakaan merupakaan serangkaian kegiatan yang berkenaan dengan metode pengumpulan data pustaka, membaca dan mencatat serta mengolah bahan penelitian (Zed, 2008). Oleh karena itu, peneliti mengumpulkan data dari buku lalu mengkaji, atau dengan cara mengambil dari sumber bacaan yang lain yang memiliki relevansi dengan penelitian.

Teknik pengumpulan data penelitian ini diawali peneliti dengan kegiatan memilih, mencari, menyajikan dan terakhir data dianalisis. Sumber data penelitian ini berupa data-data kepustakaan yang substansinya membutuhkan tindakan pengolahan secara filosofis dan teoritis. Dalam menganalisis data, peneliti menggunakan teknik analisis isi (content analysis). Yaitu suatu teknik penelitian untuk membuat perujukan pengenalan karakteristik tertentu di dalam teks secara sistematik dan obyektif. Analisis ini peneliti lakukan agar proses memilih, membandingkan, menggabungkan dan memilah data untuk menemukan definisi hingga menemukan yang relevan (Krippendorff, 1993).

\section{HASIL DAN PEMBAHASAN}

Konsep "One Stop Browsing" Dalam Upaya Mewujudkan Layanan Informasi Yang Rekreatif 
Perkembangan zaman saat ini ditandai dengan terjadinya perubahan yang sangat cepat, perubahan dalam segala bidang kehidupan masyarakat. Perpustakan sebagai lembaga yang berorientasi pada masyarakat pemustakanya harus tanggap dengan perubahan itu jika tidak ingin ditinggalkan. Perpustakaan harus cepat beradaptasi dengan perkembangan yang terjadi.

Seperti yang dikatakan Pendit, jika perpustakaan saat ini tidak perlu mengubah fungsi utama perpustakaan yang dijalaninya kini, namun harus menyesuaikan dengan perkembangan zaman. Untuk itu perpustakaan harus berkerja keras untuk meningkatkan efesiensinya dengan memunculkan konsep terbaru (Pendit, 2007).

Perkembangan ini menyebabkan perpustakaan bertanformasi dengan menawarkan sesuatu yang berbeda dan memberikan kenyamanan kepada pemustaka. Dari mulai fasilitas ruangan dengan desain yang minimalis, menelusuri informasi dengan fasilitas internet gratis dan ditambah dengan cafe perpustakaan, sehingga memberikan kesan coazy untuk memberikan rasa senang dan nyaman bagi pengunjungnya. selain memberikan ketenangan dan kenyamanan pemustaka, perpustakaan perlu memberikan pelayanan prima layaknya pelayanan market yang menyediakan semua produk dalam satu tempat yang dikenal dengan konsep one stop shopping.

Konsep one stop shopping ini diperkenalkan tahun 1980-an dan menjadi popular 1990-an. Hal ini berawal dar cara toko-toko dalam menarik pembeli dengan konsep "One Stop Shopping". Sebuah konsep berbelanja apa pun kebutuhan dalam sekali pemberhentian (Ma'ruf, 2006). Diharapkan dengan adanya OSS (One Stop Shopping) mampu mensuplai kebutuhan semua pelanggan dalam satu lingkup/komplek. Sebagai contoh Mall di Indonesia disediakan berbagai jasa dan produk untuk semua orang sehingga seseorang yang datang ke lokasi itu tidak lagi perlu berpindah dari satu lokasi ke lokasi lain untuk mendapatkan yang diinginkannya. Artinya bagaimana menarik pengunjung agar belanja segala sesuatu kebutuhan pada satu toko tanpa harus keluar ke toko lain.

Dari hal tersebut kemudian muncul salah satu konsep yang menarik untuk mewujudkan perpustakaan memberikan layanan yang rekreatif adalah dengan menerapkan konsep "One Stop Browsing" adalah dimana perpustakaan dapat menyediakan bermacam-macam layanan perpustakaan di dalam satu gedung secara lengkap, sehingga pengunjung tak perlu lagi harus pergi keluar gedung untuk mencari bahan pustaka yang dibutuhkan. Sangat menyenangkan bila konsep ini bisa diaplikasikan diperpustakaan.

Di era globalisasi seperti sekarang ini memang manusia sangat ingin mendapatkan kemudahan, keakuratan, dan kecepatan dalam memperoleh informasi, begitu juga para pengunjung perpustakaan. Oleh karena itu, sebuah gedung perpustakaan yang sangat lengkap diharapkan oleh pengunjung agar semua kebutuhannya akan informasi dapat dipenuhi dengan cepat dan tepat.

Saat ini banyak perpustakaan perguruan tinggi yang mempunyai fasilitas yang lengkap, namunbelumbanyakdikunjungiolehpengguna karena masih terkesan kaku dari segi pelayanan dan peraturan. Namun jika kita melihat market dalam hal penataan barang dan rambu-rambu yang dipasang, faslitas, interior ruangan yang membuat kita nyaman dan ingin berada lama disana dan service yang memuaskan 
pelanggan. Semua barang tertata secara rapi. Belum lagi dengan promosi dan discount yang berganti setiap saat memanfaatkan momen yang ada. Pustakawan hendaknya mengadopsi sistem seperti supermarket dengan mempromosikan koleksi dan jasa perpustakaan yang menarik. Agresivitas pustakawan dalam hal ini hendaknya sama seperti pedagang yang memasarkan barangnya.

Konsep "One Stop Browsing" sangat inovatif dan dapat diterapkan di perpustakaan tinggi, bahkan dapat dimulai dengan yang paling sederhana sekalipun. Yang perlu diingat ketertarikan dari suatu ruangan ke ruang lain yang berkesinambungan serta beberapa fasilitas penunjang selain bahan pustaka memberikan feedback positif bagi pengunjung yang datang ke perpustakaan. Adapun beberapa fasilitas penunjang yang dapat disediakan di perpustakaan antara lain:

\section{a. Lobby}

Menurut Sulistyo Basuki, perpustakaan umum yang modern membangun ruang masuk, seperti ruang penerimaan tamu sebuah hotel. Walau nampaknya ruang lobby tidak berhubungan langsung dengan bahan pustaka, tetapi ruangan ini sangat mendukung bagi pengunjung perpustakaan. beberapa orang dapat membuat janji untuk bertemu di ruang lobby atau dapat juga untuk menempel beberapa pengumuman dan promosi perpustakaan, dan melaksanakan program pameran buku.

\section{b. Library Lounge}

Library lounge adalah ruangan yang diperuntukkan bagi pemustaka duduk untuk bersantai dalam belajar. Ruangan ini biasa disediakan faslitas tempat duduk yang nyaman, disediakan sofa, televisi, dan bisa membawa makanan ke dalam ruangan tersebut serta pengguna bisa santai berdiskusi di sana.

\section{c. Counter mini}

Perpustakaan dapat menyediaka sebuah counter mini dekat yang menjual beberapa kebutuhan sederhana yang dapat dibawa masuk keruangan baca, misalnya ATK, bahkan makanan dan minuman juga dapat disediakan.

\section{d. Computer searching}

Saat ini di perpustakaan sangat dibutuhkan komputer. Fasilitas ini digunakan sebagai alat bantu penelusuran bahan pustaka yang memudahkan pemustaka. Fasilitas computer hendaknya disediakan di setiap lantai perpustakaan.

\section{e. Mesin fotocopy}

Penempatan mesin fotokopi di ruang yang salah menjadikan alat tersebut tidak dimanfaatkan secara maksimal. Sebaiknya diletakkan diruang dimana terdapat koleksi referensi dan majalah mendapat prioritas untuk diberi fasilitas mesin fotokopi.

\section{f. Internet}

Internet di perpustakaaan adalah daya tarik bagi pengunjug perpustakaan serta di dukung dengan kapasitas jaringan yang cepat.

\section{g. Televisi}

Saat ini televsi adalah alat informasi yang cepat dan murah yang banyak digemari masyarakat. Penempatan televisi di perpustakaan akan menambah ragam sarana penelusuran informasi. Yang harus diingat bahwa pemilihan channel stasiun televisi serta digunakan alat bantu earphone.

\section{h. Ruang teater}

Ruang ini ditujukan untuk menunjang fungsi rekreasi dan fungsi edukasi bagi pemustaka. Ruangan ini diperuntukkan untuk menampilkan berbagai penyelenggaraan kegiatan-kegiatan pertunjukan seni dan budaya, sosialisasi, juga diskusi ilmiah. Ruangan 
ini juga dapat difungsikan sebagai kuliah mahasiswa secara daring (dalam jaringan). Ruangan ini juga dapat dimanfaatkan sebagai ruangan rileksasi bagi pemustaka yang ingin menyaksikan film-film yang memuat local content.

Disamping itu, untuk menambah suasana yang cozy dan menyenangkan perlu didukung dengan desain interior dan eksterior, serta fasilitas santai di perpustakaan agar pemustaka merasa betah untuk berlama-lama di perpustakaan. Penempatan sofa dan meja tunggal disudut ruang baca, menggelar karpet dan menempatkan meja rendah untuk pengunjung yang ingin membaca sambil duduk di bawah, serta toilet yang tersedia di setiap lantai akan menambah pengunjung perpustakaan.

Sementara untuk interior ruangan dapat diberikan gambar-gambar yang menarik atau slogan yang membangkitkan minat baca masyarakat. Ini semua dapat mengisi dindingdinding kosong diruang baca.

\section{E. PENUTUP}

Fungsi utama perpustakaan perguruan tinggi adalah memberikan layanan kepada civitas akademika di bidang pstaka dalam rangka pelaksanan Tri Dharma Perguruan Tinggi berupa pendidikan, pengajaran, penelitian dan pengabdian di masyarakat.

Dalam menjalankan fungsinya perpustakaan sebagai pusat layanan informasi, perpustakaan dituntut untuk untuk berupaya mengembangkan diri guna memenuhi kebutuhan informasi masyarakat. Sementara itu, tanpa harus tanpa meninggalkan kaidah-kaidah utama pengelolaan perpustakaan, faktor rekreasi di dalam perpustakan sebenarnya dapat diunggulkan, karena dari sana memungkinkan banyak pengunjung yang berdatangan. Untuk itu perpustakaan harus berkerja keras untuk meningkatkan efesiensinya dengan memunculkan konsep terbaru.

Salah satu konsep yang menarik untuk mewujudkan perpustakaan yang rekreatif adalah dengan menerapkan konsep "One Stop Browsing" dimana perpustakaan dapat menyediakan bermacam-macam layanan perpustakaan di dalam satu gedung secara lengkap, sehingga pengunjung tak perlu lagi harus pergi keluar gedung untuk mencari bahan pustaka yang dibutuhkan.

Konsep "One Stop Browsing" bisa diterapkan di perpustakaan tinggi, bahkan dapat dimulai dengan yang paling sederhana sekalipun. Adapun beberapa fasilitas penunjang yang dapat disediakan di perpustakaan antara lain: lobby, counter kecil dekat locker, komputer searching, mesin fotocopy, internet dan televisi.

Di samping itu, untuk mewujudkan suasana yang hangat dan menyenangkan perlu ditunjang dengan interior dan eksterior perpustakaan agar pengunung merasa betah untuk berlama-lama di perpustakaan.

\section{DAFTAR PUSTAKA}

Basuki, S. (2002). Pengembangan Sumberdaya Manusia dalam Mengadapi Era Globalsasi dan Otonomi. Seminar Nasional Perpustakaan, 20-24. Semarang: UPT. Perpustakaan Universitas Dipenogoro.

Basuki, S. (2013). Pengantar Ilmu Perpustakaan. Jakarta: Universitas Terbuka.

Krippendorff, K. (1993). Content Analysis: Introduction Tolts Theory and Methodology. Jakarta: Raja Garfindo Persada.

Ma'ruf, H. (2006). Pemasaran Ritel. Jakarta: Gramedia Pustaka Utama.

Meier, K. F. (1983). Membina Minat Baca anak (Terjemahan). Bandung: Remadja Karya. 
Pendit, P. L. (2007). Perubahan Orientasi Dalam Informasi. Seminar Sehari Layanan Pusdokinfo Berorientasi Pemakai Di Era Informas, 7-9. Jakarta: Univesitas Indonesia.

Perpustakaan Nasional RI. (2007). Undang-Undang Republik Indonesia No.43 Tahun 2007 Tentang Perpustakaan. Jakarta: Perpustakaan Nasional RI.

Suroeno. (2016). Pendidikan Pemustaka Pada Perpustakaan Perguruan Tinggi. Media Pustakawan, 3(4), 12-14.

Zed, M. (2008). Metode Penelitian Kepustakaan. Jakarta: Yayasan Obor Indonesia.

Zein, R. H. (2006). Etika Kepustakawanan, . Jakarta: Agung Seto. 